\title{
Post-pandemic citizenship: The next phase of global citizenship education
}

\author{
Evan Saperstein ${ }^{1}$
}

Accepted: 2 October 2021

(C) UNESCO IBE 2021

\begin{abstract}
As globalization has grown, the concept of "global citizenship" has also evolved. The drive to expand citizenship beyond national borders spurred a nascent discipline known as global citizenship education (GCE). This article examines the continuum from globalization, to global citizenship, to a global pandemic (Covid-19) - and how the lessons from this growing age of globalism can serve as a blueprint for a new form of global citizenship following the pandemic, defined as "post-pandemic citizenship". The first part chronicles the drive toward globalization since the second half of the 20th century. The second part details the defining traits of global citizenship. The third part calls for a new form of global citizenship that should become part of GCE and be included in global-studies-related secondary-school courses and curricula in the wake of Covid-19-a so-called post-pandemic citizenship education (PPCE) — that emphasizes public health, empathy and compassion, self-sacrifice, and cooperative spirit.
\end{abstract}

Keywords Globalization - Global citizenship - Global citizenship education · Postpandemic citizenship $\cdot$ Post-pandemic citizenship education

In recent years, the trends toward globalization have expanded the definition of citizenship beyond national borders (Acharya, 2012). The concept of "global citizenship" has become the focus of increasing attention in academic circles, spurring a nascent field of study appropriately named global citizenship education (GCE) (Brigham, 2011; Fernekes, 2016). The scope and scale of the challenge posed by the Covid-19 pandemic have served to highlight the major issues facing the world today and the continued importance of international collaboration and purpose.

Evan Saperstein

evan.saperstein@umontreal.ca

1 Faculty of Education, University of Montreal, Marie-Victorin Building, 90 Vincent-D'Indy Ave, Montreal, QC H2V 2S9, Canada 
Since 2020, the Covid-19 outbreak has brought the world to a standstill. The pandemic has upended daily life and, in so doing, it has revolutionized the way in which we work, learn, and otherwise interact (Fancera \& Saperstein, 2021). Even more, the pandemic has further exposed deep-rooted inequities in public health, the economy, race relations, and the environment. In his nomination speech for president, Joe Biden (2020) alluded to these four historic crises, including the "worst pandemic in over 100 years. The worst economic crisis since the Great Depression. The most compelling call for racial justice since the 60's. And the undeniable realities and accelerating threats of climate change".

In this article I examine the ongoing continuum from globalization, to global citizenship, to a global pandemic - and how the lessons from this growing age of globalism can serve as a blueprint for a new form of global citizenship following the pandemic, defined as "post-pandemic citizenship". In the first part, I chronicle the drive toward globalization (political, economic, and cultural) since the second half of the 20th century. In the second part, I detail the defining traits of global citizenship. In the third part, I call for a new form of global citizenship in the wake of Covid-19-a so-called post-pandemic citizenship education (PPCE) — that emphasizes public health, empathy and compassion, self-sacrifice, and cooperative spirit. This new form of citizenship should become part of GCE and be included in global-studies secondary-school related courses and curricula.

\section{The drive toward globalization}

Despite some setbacks over the years, since the second half of the 20th century there has been a growing movement toward and recognition of globalization-political, economic, and cultural. Europe is among the more notable examples of this trend. Indeed, in the aftermath of World War II, Europe began the process of transforming from a patchwork of sovereign nation-states to a community of nations (Bickerton, 2012). Through several treaties over the decades following World War II, a rising number of European countries entered into enduring political and economic alliances (McCormick, 1999; Shore, 2000). With the culmination of the European Union (EU), Europe became a more interconnected global community (Follesdal, 2002; Maas, 2014) —and with the ever-looming threat of communist takeover during the ensuing Cold War, European countries hastened to align their foreign and security policies (Feld, 1998; Saperstein, 2008). And, despite the recent Brexit movement arising out of the United Kingdom (Pettifor, 2017), through the EU and a near fifty-year Cold War, European nations created a lasting shared identity and "common citizenship status for citizens of EU member states" (Maas, 2014, p. 409).

Countries outside of Europe have also increasingly entered into cross-national agreements and unions, such as the United States-Mexico-Canada Agreement (USMCA), the African Union (AU), the Association of Southeast Nations (ASEAN), and the Southern Common Market (Mercado Común del Sur; MERCOSUR) (Shaw et al., 2011; Swanson, 2020; Telò, 2014). While these regional and continental groups do not grant the same breadth of transnational rights and freedoms as provided by the EU, they have served to strengthen political ties and to promote economic integration (Falk, 2002; Maas, 2014). Yet recent efforts to expand upon these agreements and unions have been modest at best (Natalegawa, 2018; Swanson, 2020). And, while some have welcomed global governance and "cosmopolitan democracy" (Archibugi, 2008; Caney, 2005; Held, 1995), others have lamented the rise of international institutions (Axtmann, 2002; Hawthorn, 2003; Zolo, 1997). 
Over the past few decades, economic globalization has also brought individuals, neighborhoods, local communities, and nations together (Langran, 2016; Zhao, 2014). Companies and corporations have increasingly spread to other parts of the world (Kordos \& Vojtovic, 2016). Consequently, citizens have felt less isolated and more part of a global community (Csaba, 2003; Stiglitz, 2002), leading to "important implications for the nature and prospects of global citizenship" (Newlands, 2002, p. 213).

Despite this, economic globalization can have negative consequences for global citizens (Buckman, 2004; Cavanagh et al., 2002; Langran, 2016), including higher unemployment for failing companies and deterioration of the "natural environment and the health, safety, working conditions and wages of employees" (Newlands, 2002, p. 217). Economic globalization can also favor the interests of corporations over those of everyday citizens (Cruikshank, 1998), as a growing disparity between the rich and poor, and worldwide recessions, serve as further evidence that global financial institutions have failed to cure the inequities of capitalism (Cruikshank, 1998; Tuca, 2014).

Cultural globalization has also kept pace with the political and economic trends of globalization following World War II. Take the United States, for example, which over decades has projected and exported popular culture across the globe, including cinema, music, art, commercial products, food, sports, clothing, and the internet (Crane, 2014; Crothers, 2007; Saperstein, 2010; Van Elteren, 2011). During this time period, the world has also witnessed an unprecedented telecommunications or digital revolution (e.g., computers, cellular phones, and social media) (Kolodko, 2011) that redefined global borders (Ahmad, 2013; Crothers, 2007). While some see cultural globalization as a positive force that promotes progress, understanding, and diversity among global citizens (Rothkopf, 1997; Wang, 2007), others have considered it a threat to their local identity or culture, and express skepticism that a global village, culture, or society exists in reality (Guibernau, 2007; Guillén, 2001; Hirst \& Thompson, 1996). It is through these rising political, economic, and cultural connections (and tensions) that the concept of global citizenship has emerged.

\section{The emergence of global citizenship and global citizenship education}

The concept of global citizenship is subject to ongoing interpretations and meaning and has been defined by a growing number of international bodies and institutions (Oxfam, 2006; UNESCO, 2015; UNICEF, 2013). UNESCO describes global citizenship broadly as "belonging to a broader community and common humanity", and "political, economic, social and cultural interdependency and interconnectedness between the local, the national and the global" (UNESCO, 2015, p. 14). UNICEF assigns further traits to a global citizen, including:

- Appreciation for diversity and global interconnectedness;

- Desire to confront societal inequities;

- Willingness to act meaningfully (UNICEF, 2013).

Oxfam includes similar characteristics when defining global citizenship, adding:

- Concern for environmental problems;

- Commitment to sustainability; 
- Ability to critically think and reason;

- Appreciation and empathy for others to promote conflict resolution;

- Recognition of self-worth and identity (Oxfam, 2006).

Scholars have echoed similar definitions of global citizenship (Carter, 2001; Diaz et al., 1999; Noddings, 2005; Reysen \& Katzarska-Miller, 2013). Diaz et al., (1999, p. 191) define a global citizen as one "who is characterized by an attitude of openness toward all others, irrespective of their gender, race, ethnicity, age, religion, and language". Noddings (2005) highlights the need for economic and social justice, as well as the need to protect the earth, embrace social and cultural diversity, and educate for peace. Carter (2001, p. 98) agrees that global citizens are dedicated to "social justice, diversity, sustainable economic development respecting the environment, and to a peaceful world". Reysen and KatzarskaMiller (2013) sum up global citizenship through the following six traits, detailed further below:

- Global awareness;

- Caring;

- Cultural diversity;

- Social justice;

- Sustainability;

- Responsibility to act.

\section{Global awareness}

Global awareness, the first trait of global citizenship, is about understanding the interrelated nature of the world (Dower, 2002; Pike, 2008), including "globalization and the resulting issues and problems that affect everyone's lives" (Gibson et al., 2008, p. 15). Werner and Case (1997) have defined global awareness to include knowledge of cultural principles and traditions, appreciation for the interconnected nature of global systems, understanding of global concerns, and recognition of the global past and future. Global citizenship requires global awareness to address pressing economic, social, environmental, cultural, and ethical issues (Noddings, 2005).

In business practice, employers have increasingly stressed the importance of understanding different cultures and developing 21st century skills (Bruett, 2006; Mendoza, 2007) by, for example, studying abroad (Trooboff et al., 2008). The Partnership for 21st Century Learning (2009) emphasizes in particular that global awareness promotes collaboration in the workplace and broader community. Given the demands of a rapidly changing world, global awareness has become increasingly necessary for leaders and employees of various industries (Bowerman \& Van Wart, 2014; Milman, 2015). Exhibiting global awareness can create more career opportunities, improve decision making, and enhance entrepreneurial and leadership skills (Goldsmith, 2012).

In education, colleges and universities also have increasingly emphasized studying abroad as a way to learn another language and become more culturally aware (DeLoach et al., 2015; Gieser, 2015; Haring-Smith, 2011; Kurt et al., 2013; Wang et al., 2014). As Clarke (2004, p. 68) argues, "foreign languages are essential for a world of intercultural convergence" and a necessary part of a curriculum. For pre-service teachers, study abroad experiences have helped foster global citizenship and develop global awareness or cultural competency in languages, values, and customs (Byker \& Putman, 2019; Klein \& Wikan, 
2019; Kyei-Blankson \& Nur-Awaleh, 2018). While pre-service teachers tend to have more study abroad opportunities, in-service teachers also benefit from programs that emphasize cultural immersion, teaching, language acquisition, reflection, and collaboration (He et al., 2017). In-service teachers may even further their intercultural knowledge and global awareness through short-term (two to eight weeks) study abroad programs (He et al., 2017; Reimers, 2020).

At the same time, adding global citizenship to textbooks (Lee, 2020) or resource books used in primary and secondary schools can help to nurture "globally aware, globally minded, and globally proficient" students (Reimers, 2020, p. 1). For instance, the three-step model known as Global Citizenship 1-2-3 helps students to learn, think, and act responsibly by developing global awareness through experiential learning (Putman \& Byker, 2020). Sisk (2010) and Roeper (2008) focus specifically on gifted children or students "who exhibit high ability across one or more academic subject areas" (Bates \& Munday, 2005, p. 4). Their studies have shown that gifted students, with the support of loving and caring adults, can develop the global awareness of a global citizen—that is, "empathy and sensitivity to justice, honesty, fairness, and a sense of responsibility for making a difference" (Sisk, 2010, p. 10), and "aware[ness] of the world around them" (Roeper, 2008, p. 9). In sum, incorporating global awareness into curricula has helped students to understand and address important 21st-century challenges (Burnouf, 2004).

\section{Caring}

Caring for the global community and humanity is a responsibility shared by globally conscious citizens (Dill, 2013). According to UNESCO (2015, p. 29), one of the key learner attributes for a global citizen is "to develop motivation and willingness to care for the common good". For instance, in the medical field, nurses care for a global population that transcends borders and cultural barriers (Cesario, 2017). Indeed, to be both a global citizen and a cosmopolitan nurse, "requires participation in, and valuing of, the common good of society as a whole" (Petit dit Dariel, 2009, p. 569).

"Caring" is also an important ethos for teachers entering the profession (Hawks \& Pillay, 2017). Over the past few decades, countries like Sweden have started to incorporate the principle of "care" into their pedagogy for students at an early age (Johansson, 2009). Ruby (2014, p. 54) concludes that "as we debate the ways to educate young people for global roles ... a duty of all is ... to care for others".

\section{Cultural diversity}

Global citizenship also emphasizes "shared membership and shared global values" (Mullens \& Cuper, 2012, p. 44), and "embracing cultural diversity" (Reysen \& KatzarskaMiller, 2013, p. 860). Ibrahim (2004) specifically connects global citizenship with the concept of "cultural diversity", calling for organizations to promote multiculturalism both locally and globally. Additionally, UNESCO (2002, p. 62) noted in its Universal Declaration on Cultural Diversity that cultural diversity is "the common heritage of humanity" and "is embodied in the uniqueness and plurality of the identities of the groups and societies making up humankind". 
In Spain, for instance, cultural diversity is part of a broader educational curriculum (Engel, 2014). Exploring Spain's 2006 Education for Citizenship and Human Rights curriculum (replaced in 2013) along with corresponding textbooks, Engel (2014, p. 251) explains that "cultural diversity is conveyed largely through non-threatening ideas of global connections such as in relation to food, festivals, and flags". The 2016 Annual Report of National Commissions for UNESCO also emphasizes cultural diversity and interdependence as part of a global-citizenship-related curriculum (UNESCO, 2016). Banks (2003, p. 19) maintains the importance of citizens in diverse democratic societies being literate, thoughtful, ethical, and engaged "citizens of their nation and the world".

Others, however, have expressed concern that shared global values may discourage cultural diversity (Arneil, 2007; Cheng, 2012). Cheng (2012, p. 157) speaks to the concerns of undermining the character of local cultures and instead calls for "a global mosaic of multiple, pluralistic knowledge societies, each rooted in its own unique cultural identity". Arneil (2007, p. 315) also takes issue with "anchoring citizenship at the global level in a set of shared values", warning of "the potential to do violence to cultural diversity at best or engage in western cultural imperialism at worst". As Zayani (2011, p. 49) concludes, preserving cultural diversity "is a complex endeavor".

\section{Social justice}

Social justice broadly refers to a process whereby every individual or group works to challenge oppression and receive the same opportunity, (Bell, 2007; Bhugra, 2016; Garcia \& Van Soest, 2006; Greene, 1998) inclusive of not only cultural but also racial, religious, ethnic, and language diversity (Banks, 2004). Scholars have expressly tied the principle of "social justice" to a globalizing world (Brock, 2009; Fraser, 2009). Brock (2009), for instance, calls for a cosmopolitan model of global justice that addresses various international challenges while preserving the national identity of citizens. To achieve social justice in a globalizing world, Fraser (2009) speaks to redistribution (socioeconomic opportunity), recognition (social identity or standing), and representation (political affairs).

Moreover, social justice education and pedagogy have provided teachers with growing opportunities to raise social awareness in the classroom (Adams, 2007; Hytten, 2015). Adams (2007, p. 30) notes that educators can foster "connections between awareness and action by helping participants recognize various spheres of influence in their daily lives". Howe and $\mathrm{Xu}$ (2013) also stress social action, calling for teachers to play a significant role in fostering both social justice and global citizenship. With the assistance and guidance of teachers, students can learn to "share the world and live together in harmony and peace" (Howe \& Xu, 2013, p. 41).

\section{Sustainability}

Global citizenship also requires sustainability-environmental, economic, and social. Environmentally speaking, scholars have recognized the responsibility citizens share in affecting our supply of natural resources and materials (Dobson, 2011; Heater, 2004; Marzall, 2005). Heater (2004, p. 12) views it as "a moral responsibility"; Marzall (2005) advocates for environmental laws and ethics; and Dobson (2011, p. 10) stresses "fairness of the distribution of environmental goods". To address climate change and other critical 
environmental challenges, educational institutions have accordingly recognized the importance of sustainability research (Brundiers \& Wiek, 2011; Rowe, 2007).

Economically speaking, to build a more sustainable and just society, Penner and Sanderse (2017) call for the inclusion of economic citizenship education (ECE) in school curricula at the local, national, and global level. Ensuring long-term economic sustainability is also critical at the organizational level, as companies seek to adopt responsible management strategies and practices (Laasch \& Conaway, 2015). And, socially speaking, Barbier (1987) broadly defines sustainability as adhering to values, customs, and characteristics. Polèse and Stren (2000, pp. 15-16) define it as "compatible cohabitation of culturally and socially diverse groups . . . encouraging social integration". For example, in a business setting, social sustainability refers to a "corporation internally creat[ing] a supportive and developmental environment for staff" (Benn \& Bolton, 2011, p. 64). Tying these concepts together, global citizens have an environmental, economic, and social responsibility to protect and safeguard the quality of life and rights of others through community initiatives (Leslie, 2009).

\section{Responsibility to act}

The responsibility to act requires a global citizen who "knows how the world works, is outraged by injustice and who is both willing and enabled to take action to meet this global challenge" (Oxfam, 1997, p. 1). Responsibility also "involves being proactive, and taking the initiative . . rather than waiting for others to take the first steps" (Schattle, 2008, p. 44). Global citizens feel a duty to initiate change, inspiring others to join the cause on their own volition (Schattle, 2008). One of the more notable, widereaching examples of this commitment to act is the Global Poverty Project cofounded by Hugh Evans and Simon Moss in 2008 (Bryan, 2016; McKinley, 2012). Among the global citizenship initiatives of this project is the Global Citizen Festival, which brings world leaders, celebrities, and activists together to raise awareness and money for global causes (Bryan, 2016).

There are other important, albeit less publicized, examples of action initiatives. For example, William Gaudelli (2016) designed and cofounded the Global Competence Certificate (GCC) program at Columbia University's Teachers College (Levine, 2014). Partnering with World Savvy and the Asia Society, this program helps teachers become more proficient in global issues by taking online courses and traveling abroad to Bangladesh, Tanzania, Colombia, or Uganda (Levine, 2014). Another initiative, the Belize Education Project, encourages students and teachers in the United States and Belize to take action and create lasting partnerships (Fry et al., 2012). Moreover, The Global Citizens' Initiative (TGCI), founded by Ron Israel (2012), strives to further the goals of global citizenship through advocacy, citizen engagement, and education.

To initiate this call to action and educate for global citizenship, Gaudelli (2015) proposes three recommendations: adopting curricular reforms; encouraging teachers and students to embrace exchange programs and online discussion forums; and calling for citizens to create gardens and grow food in order for students to better understand the ecosystem. Through dialogue and collaboration, teachers can effect change in the classroom and prepare citizens to meet some of the pressing global challenges (Gaudelli, 2016). As Gunzelmann (2014, p. 173) concludes, "We all must come to terms and step 
up to take responsibility, for each and every one of us plays an important part in the outcome of our global world".

\section{Post-pandemic citizenship}

The Covid-19 pandemic is far from over. But it is clear from the past year that the pandemic has revealed the depth of many challenges that global citizens have sought for years to address. As months turn to years, and as the world tries to rebuild in the aftermath of the pandemic, it is imperative that a new sense of global citizenship guide international efforts regarding public health, economic and social justice, the environment, and much more. Accordingly, in light of the Covid-19 pandemic and the ensuing results, the concept of global citizenship should expand to include a new form of such citizenship-a postpandemic citizenship - to rebuild a better world in the wake of a once-in-a-century pandemic. Indeed, to repair a post-pandemic world, post-pandemic citizens should dedicate themselves to promoting public health, exhibiting empathy and compassion, committing to self-sacrifice, and embracing a cooperative spirit locally, nationally, and globally.

First, as it relates to public health, to further post-pandemic citizenship, governments across the world should continue collaborating and investing more in research to prevent future pandemics. This begins with a sustained worldwide campaign to develop and distribute safe and effective Covid-19 vaccines (McCausland, 2020). In particular, highincome countries must work together to disseminate and administer more vaccine doses to middle-income and low-income countries. One such initiative, the Covid-19 Vaccine Global Access (COVAX) program, has regrettably fallen short of its initial delivery target for several reasons, including vaccine nationalism (nations putting their own vaccine supply needs and interests above everyone else) (Eccleston-Turner \& Upton, 2021; Leggae $\&$ Kim, 2021). With increased global cooperation, COVAX and similar initiatives should strive to ensure more vaccine equity between wealthy and poor nations. As Katz et al. (2021, p. 1283) point out, "such cooperation is not only a matter of social justice, it is also a sound pragmatic response to ending a pandemic in which a virus and its variants easily cross borders". At the same time, global citizens in the medical community should build on vaccine technology (i.e., using mRNA to stimulate an immune response) to address other current health issues.

Second, given the tragic toll on human life resulting from the Covid-19 pandemic, a post-pandemic citizen should demonstrate the level of empathy and compassion needed in a post-pandemic world. Empathy includes listening, committing acts of service, and being attentive to the plight of others (Singh \& Singh, 2020). Citizens must demonstrate not only empathy but also compassion for others and oneself (Galea, 2020; Slavich et al., 2021). Exhibiting compassion could include assisting members in the community (e.g., providing emotional, social, financial, or medical support), especially the vulnerable population. Selfcompassion refers to valuing one's own well-being (Slavich et al., 2021).

Third, a post-pandemic citizen should commit to self-sacrifice to protect the common good of society over individual self-interests. Hollings (2020, p. 87) explains that it "requires a caring citizen, one who cares about the potential for others to get sick". While the Covid-19 pandemic has brought out the very best in many citizens, it also has exposed an unprecedented level of selfishness and ignorance. Too many consistently defied safety protocols established by infectious disease specialists and public health experts. Take mask-wearing as an example. In certain countries, not wearing a mask has become a political statement even though the science is settled on its efficacy (He \& Laurent, 2020). Not 
practicing social distancing (staying two meters [six feet] apart) also has turned into a political act even when the data proves that it slows the spread of infection (Ansell et al., 2021; Zimmerman \& Benjamin, 2021). As Slavich et al. (2021, p. 5) explain, "reframing physical isolation as a necessary act of solidarity and togetherness may help promote perceptions of social integration and belonging in the face of the Covid-19 pandemic". This pandemic has served as a painful reminder of putting the well-being of others ahead of our own self-interest and indulgences. As such, government leaders, public health officials, and everyday citizens have a responsibility to promote the collective good in the future, even if it is at the so-called expense of individual liberty.

Fourth, a post-pandemic citizen should embrace a cooperative spirit locally, nationally, and globally - and there have been a number of examples of such cooperation since the pandemic. At the local level, citizens benefit from uniting behind a common cause and purpose. Throughout the Covid-19 pandemic, many local schools, businesses, and agencies around the world - in the name of public health and safety-were asked to comply with guidelines to slow the spread of the virus (UN, 2020). At the national level, many governments have encouraged cooperation among public- and private-sector institutions (OECD, 2020)—whether they be research institutes, universities, businesses, or nonprofit organizations. These public-private partnerships have collectively shared resources, risks, and rewards to accelerate the production of therapeutics and vaccines (Deloitte, 2020). At the global level, various institutions developed an international strategy to contain and defeat the pandemic (UN, 2020). This included distributing medical equipment, treatments, and vaccines, while strengthening existing multilateral institutions to prevent similar crises in the future (UN, 2020).

\section{Post-pandemic citizenship education}

Global citizenship "focuses on preparation for civic engagement in increasingly diverse and global contexts" (Whitehead, 2015, p. 8). As global citizenship has emerged, so too has GCE in secondary school curricula across various countries (Bickmore, 2014; Brown et al., 2009; Chong, 2015; Davies et al., 2005; Evans et al., 2009; Motani, 2007; Myers, 2020). GCE is perhaps best defined as an instructional field that seeks to hone students' critical thinking skills while teaching them to be agents of change in society (Bickmore, 2009; Peterson \& Warwick, 2015; UNESCO, 2015). GCE also seeks to strengthen crosscultural awareness through the study of contemporary international issues and provide students with the requisite knowledge, skills, and values to actively participate in a global society (Gallavan, 2008; Guo, 2014; Maguth, 2012; Myers, 2006).

In response to the Covid-19 pandemic, secondary schools should reexamine the scope and sequence of knowledge, skills, and values within GCE curricula to address the lessons of the pandemic. As such, this article proposes that secondary schools begin to offer a GCE-type course or content that includes, as a minimum, the following five PPCE-related units.

First unit The first unit should introduce and define "post-pandemic citizenship". Students should discuss the key traits of a post-pandemic citizen. Students also should write an essay on what it means to be a post-pandemic citizen. 
Second unit The second unit should examine the public health issues that arise during a pandemic. Students should study how different countries prepared and responded to Covid-19 and other pandemics throughout history. Students should also discuss how to create effective prevention and treatment programs along with vaccines. Students should then develop an action plan to confront a future pandemic.

Third unit The third unit should address the importance of instilling empathy and compassion in citizens. Students should explore ways to understand and identify with citizens facing other global health challenges, including poverty, world hunger, child mortality, and malnutrition. Through inquiry-based learning, students should conduct scholarly research and prescribe solutions to these problems.

Fourth unit The fourth unit should explore the concept of self-sacrifice. Students should consider scenarios where citizens choose collective responsibility over their own self-interest. Through simulations and social media campaigns, students should discuss how to sacrifice for the collective good in the areas of health, economics, social justice, and the environment.

Fifth unit The fifth unit should emphasize the importance of embracing a cooperative spirit. Students should examine current local, national, and global initiatives as well as the civic duties of a post-pandemic citizen. Through projectbased and experiential learning, students should research a global challenge and develop an action plan for a post-pandemic world.

\section{Conclusion}

Since the second half of the 20th century, the concept of global citizenship has grown out of the rising tides of political, economic, and cultural globalization. These citizens are defined by several key traits, including global awareness, caring, embracing cultural diversity, advocating for social justice, promoting sustainability, and the responsibility to act (Reysen \& Katzarska-Miller, 2013). Consequently, GCE has sought to promote these concepts and develop students' analytical and critical thinking skills, while drawing connections between local and global issues.

In response to the COVID-19 pandemic, educational institutions at the secondary level should begin to emphasize a new form of global citizenship, post-pandemic citizenship, in global-studies-related courses and curricula (PPCE). By focusing on public health, empathy and compassion, self-sacrifice, and a cooperative spirit, the next generation of global citizenry can begin the process of navigating a post-pandemic world.

\section{References}

Acharya, A. (Ed.) (2012). Citizenship in a globalizing world. Pearson Education.

Adams, M. (2007). Pedagogical frameworks for social justice education. In M. Adams, L. A. Bell, \& P. Griffin (Eds.), Teaching for diversity and social justice (2nd ed., pp. 15-33). Routledge.

Ahmad, A. (2013). New age globalization: Meaning and metaphors. Palgrave Macmillan.

Ansell, B., Cansunar, A., \& Elkjaer, M. A. (2021). Social distancing, politics and wealth. West European Politics, 44(5-6), 1283-1313. 
Archibugi, D. (2008). The global commonwealth of citizens: Toward cosmopolitan democracy. Princeton University Press.

Arneil, B. (2007). Global citizenship and empire. Citizenship Studies, 11(3), 301-328.

Axtmann, R. (2002). What's wrong with cosmopolitan democracy? In N. Dower \& J. Williams (Eds.), Global citizenship: A critical introduction (pp. 101-113). Routledge.

Banks, J. A. (2003). Teaching literacy for social justice and global citizenship. Language Arts, 81(1), 18-19.

Banks, J. A. (2004). Teaching for social justice, diversity, and citizenship in a global world. The Educational Forum, 68(4), 296-305.

Barbier, E. B. (1987). The concept of sustainable economic development. Environmental Conservation, 14(2), 101-110.

Bates, J., \& Munday, S. (2005). Able, gifted and talented. Continuum.

Bell, L. A. (2007). Theoretical foundations for social justice education. In M. Adams, L. A. Bell, \& P. Griffin (Eds.), Teaching for diversity and social justice (pp. 1-14). Routledge.

Benn, S., \& Bolton, D. (2011). Key concepts in corporate social responsibility. Sage.

Bhugra, D. (2016). Social discrimination and social justice. International Review of Psychiatry, 28(4), $336-341$.

Bickerton, C. J. (2012). European integration: From nation-states to member states. Oxford University Press.

Bickmore, K. (2009). Global education to build peace. In T. Kirkwood-Tucker (Ed.), Visions in global education: The globalization of curriculum and pedagogy in teacher education and schools-Perspectives from Canada, Russia, and the United States (pp. 270-285). Peter Lang.

Bickmore, K. (2014). Citizenship education in Canada: "Democratic" engagement with differences, conflicts and equity issues? Citizenship Teaching \& Learning, 9(3), 257-278.

Biden, J. (2020). Joe Biden's DNC Speech [Transcript]. https://www.cnn.com/2020/08/20/politics/bidendnc-speech-transcript/index.html

Bowerman, K. D., \& Van Wart, M. (2014). The business of leadership: An introduction. Routledge.

Brigham, M. (2011). Creating a global citizen and assessing outcomes. Journal of Global Citizenship \& Equity Education, 1(1), 15-43.

Brock, G. (2009). Global justice: A cosmopolitan account. Oxford University Press.

Brown, E. J., Morgan, W. J., \& McGrath, S. (2009). Education, citizenship and new public diplomacy in the UK: What is their relationship? Citizenship, Social and Economics Education, 8(2), 73-83.

Bruett, K. (2006). Why American business demands twenty-first century skills: An industry perspective. New Directions for Youth Development, 110, 25-30.

Brundiers, K., \& Wiek, A. (2011). Educating students in real-world sustainability research: Vision and implementation. Innovative Higher Education, 36(2), 107-124.

Bryan, A. (2016). Global citizenship as public pedagogy: Emotional tourism, feel-good humanitarianism, and the personalization of development. In I. Langran \& T. Birk (Eds.), Globalization and global citizenship: Interdisciplinary approaches (pp. 115-128). Routledge.

Buckman, G. (2004). Globalization: Tame it or scrap it? Zed Books.

Burnouf, L. (2004). Global awareness and perspectives in global education. Canadian Social Studies, 38(3), $1-12$.

Byker, E. J., \& Putman, S. M. (2019). Catalyzing cultural and global competencies: Engaging preservice teachers in study abroad to expand the agency of citizenship. Journal of Studies in International Education, 23(1), 84-105.

Caney, S. (2005). Justice beyond borders: A global political theory. Oxford University Press.

Carter, A. (2001). The political theory of global citizenship. Routledge.

Cavanagh, J., \& Mander, J. (Eds.) (2002). Alternatives to economic globalization: A better world is possible. Berrett-Koehler.

Cesario, S. K. (2017). What does it mean to be a global citizen? Nursing for Women's Health, 21(1), 59-63.

Cheng, L. (2012). Cultural diversity in a global society. Science, 336(6078), 155-157.

Chong, E. K. M. (2015). Global citizenship education and Hong Kong's secondary school curriculum guidelines. Asian Education and Development Studies, 4(2), 221-247.

Clarke, V. (2004). Students' global awareness and attitudes to internationalism in a world of cultural convergence. Journal of Research in International Education, 3(1), 51-70.

Crane, D. (2014). Cultural globalization and the dominance of the American film industry: Cultural policies, national film industries, and transnational film. International Journal of Cultural Policy, 20(4), $365-382$.

Crothers, L. (2007). Globalization and American popular culture. Rowman \& Littlefield.

Cruikshank, J. (1998). Are we aiding the enemy? Adult education in the global economy. Canadian Journal of University Continuing Education, 24(1), 101-113. 
Csaba, L. (2003). Globalization and economic systems: A homogeneity test. In A. Krizsán \& V. Zentai (Eds.), Reshaping globalization: Multilateral dialogues and new policy initiatives (pp. 195-214). Central European University Press.

Davies, I., Evans, M., \& Reid, A. (2005). Globalising citizenship education? A critique of "global education" and "citizenship education." British Journal of Educational Studies, 53(1), 66-89.

DeLoach, S. B., Kurt, M., \& Olitsky, N. H. (2015). Does content matter? Analyzing the change in global awareness between business- and nonbusiness-focused short-term study abroad courses. Journal of Teaching in International Business, 26(1), 4-31.

Deloitte. (2020). Securing trust in the global COVID-19 supply chain. https://www2.deloitte.com/content/ dam/Deloitte/global/Documents/Life-Sciences-Health-Care/gx-lshc-future-of-trust.pdf

Diaz, C., Massialas, B., \& Xanthopoulos, J. (1999). Global perspectives for educators. Allyn \& Bacon.

Dill, J. S. (2013). The longings and limits of global citizenship education: The moral pedagogy of schooling in a cosmopolitan age. Routledge.

Dobson, A. (2011). Sustainability citizenship. Greenhouse.

Dower, N. (2002). Global citizenship: Yes or no? In N. Dower \& J. Williams (Eds.), Global citizenship: A critical introduction (pp. 30-40). Routledge.

Eccleston-Turner, M., \& Upton, H. (2021). International collaboration to ensure equitable access to vaccines for COVID-19: The ACT-Accelerator and the COVAX facility. The Milbank Quarterly, 99(2), $426-449$.

Engel, L. C. (2014). Global citizenship and national (re)formations: Analysis of citizenship education reform in Spain. Education, Citizenship and Social Justice, 9(3), 239-254.

Evans, M., Ingram, L., MacDonald, A., \& Weber, N. (2009). Mapping the "global dimension" of citizenship education in Canada: The complex interplay between theory, practice and context. Citizenship Teaching and Learning, 5(2), 16-34.

Falk, R. (2002). An emergent matrix of citizenship: Complex, uneven, and fluid. In N. Dower \& J. Williams (Eds.), Global citizenship: A critical introduction (pp. 15-29). Routledge.

Fancera, S. F., \& Saperstein, E. (2021). Preparations, expectations, and external school contexts: Navigating the COVID-19 school closures. Journal of Organizational and Educational Leadership, 6(3), 1-35.

Feld, W. J. (1998). The integration of the European Union and domestic political issues. Praeger.

Fernekes, W. R. (2016). Global citizenship education and human rights education: Are they compatible with U.S. civic education? Journal of International Social Studies, 6(2), 34-57.

Follesdal, A. (2002). Citizenship: European and global. In N. Dower \& J. Williams (Eds.), Global citizenship: A critical introduction (pp. 71-83). Routledge.

Fraser, N. (2009). Scales of justice: Reimagining political space in a globalizing world. Columbia University Press.

Fry, S., Griffin, S., \& Kirshner, J. (2012). Learning global citizenship: Students and teachers in Belize and the U.S. take action together. Social Studies and the Young Learner, 25(2), 23-27.

Galea, S. (2020). Compassion in a time of COVID-19. The Lancet, 395(10241), 1897-1898.

Gallavan, N. P. (2008). Examining teacher candidates' views on teaching world citizenship. The Social Studies, 99(6), 249-254.

Garcia, B., \& Van Soest, D. (2006). Social work practice for social justice: Cultural competence in action. Council on Social Work Education.

Gaudelli, W. (2015). A call for global citizenship education. Education Week. https://www.edweek.org/policy-politics/opinion-a-call-for-global-citizenship-education/2015/07

Gaudelli, W. (2016). Global citizenship education: Everyday transcendence. Routledge.

Gibson, K. L., Rimmington, G. M., \& Landwehr-Brown, M. (2008). Developing global awareness and responsible world citizenship with global learning. Roeper Review, 30(1), 11-23.

Gieser, J. D. (2015). A sociocultural investigation of identity: How students navigate the study abroad experience. Journal of College Student Development, 56(6), 637-643.

Goldsmith, D. (2012). Enhancing global awareness: Paid to think. BenBella Books.

Greene, M. (1998). Introduction: Teaching for social justice. In W. Ayers, J. A. Hunt, \& T. Quinn (Eds.), Teaching for social justice: A democracy and education reader (pp. xxvii-xlvi). Teachers College Press.

Guibernau, M. (2007). The identity of nations. Polity.

Guillén, M. (2001). Is globalization civilizing, destructive or feeble? A critique of five key debates in the social science literature. Annual Review of Sociology, 27, 235-260.

Gunzelmann, B. (2014). Global voices and global visions: Education for excellence, understanding, peace and sustainability. Rowman \& Littlefield.

Guo, L. (2014). Preparing teachers to educate for 21st century global citizenship: Envisioning and enacting. Journal of Global Citizenship \& Equity Education, 4(1), 1-23. 
Haring-Smith, T. (2011). The Magellan Project: Developing global citizens through independent study abroad. About Campus, 16(5), 9-12.

Hawks, M., \& Pillay, T. (2017). Institutionalizing an "ethic of care" into the teaching of ethics for preservice teachers. Journal of Critical Thought and Praxis, 6(2), 66-83.

Hawthorn, G. (2003). Running the world through windows. In D. Archibugi (Ed.), Debating cosmopolitics (pp. 16-26). Verso.

He, E., \& Laurent, L. (2020). The world is masking up, some are opting out. https://www.bloomberg. com/graphics/2020-opinion-coronavirus-global-face-mask-adoption/

He, Y., Lungren, K., \& Pynes, P. (2017). Impact of short-term study abroad program: Inservice teachers' development of intercultural competence and pedagogical beliefs. Teaching and Teacher Education, 66, 147-157.

Heater, D. (2004). World citizenship: Cosmopolitan thinking and its opponents. Continuum.

Held, D. (1995). Democracy and the global order: From the modern state to cosmopolitan governance. Polity.

Hirst, P., \& Thompson, G. (1996). Globalization in question: The international economy and the possibilities of governance. Polity.

Hollings, S. (2020). COVID-19: The changing face of global citizenship and the rise of pandemic citizenship. Knowledge Cultures, 8(3), 81-91.

Howe, E. R., \& Xu, S. (2013). Transcultural teacher development within the dialectic of the global and local: Bridging gaps between East and West. Teaching and Teacher Education, 36, 33-43.

Hytten, K. (2015). Ethics in teaching for democracy and social justice. Democracy \& Education, 23(2), $1-10$.

Ibrahim, T. (2004). Global citizenship: Teaching and learning about cultural diversity. Race Equality Teaching, 22(2), 29-33.

Israel, R. (2012). Global citizenship: A path to building identity and community in a globalized world. The Global Citizens' Initiative.

Johansson, E. (2009). The preschool child of today-the world-citizen of tomorrow? International Journal of Early Childhood, 41(2), 79-95.

Katz, I. T., Weintraub, R., Bekker, L.-G., \& Brandt, A. M. (2021). From vaccine nationalism to vaccine equity - finding a path forward. The New England Journal of Medicine, 384(14), 1281-1283.

Klein, J., \& Wikan, G. (2019). Teacher education and international practice programmes: Reflections on transformative learning and global citizenship. Teaching and Teacher Education, 79(1), 93-100.

Kolodko, G. W. (2011). Truth, errors, and lies: Politics and economics in a volatile world. Columbia University Press.

Kordos, M., \& Vojtovic, S. (2016). Transnational corporations in the global world economic environment. Procedia: Social and Behavioral Sciences, 230, 150-158.

Kurt, M. R., Olitsky, N. H., \& Geis, P. (2013). Assessing global awareness over short-term study abroad sequence: A factor analysis. Frontiers, 23(fall), 22-41.

Kyei-Blankson, L., \& Nur-Awaleh, M. (2018). Shifting teacher cultural awareness and teaching through study abroad experiences. International Journal of Multidisciplinary Perspectives in Higher Education, 3(1), 31-44.

Laasch, O., \& Conaway, R. N. (2015). Principles of responsible management: Glocal sustainability, responsibility, and ethics. Cengage Learning.

Langran, I. (2016). Introduction. In I. Langran \& T. Birk (Eds.), Globalization and global citizenship: Interdisciplinary approaches (pp. 1-8). Routledge.

Lee, S. S. (2020). Fostering "global citizens"? Trends in global awareness, agency, and competence in textbooks worldwide 1950-2011. Prospects, 48, 215-236.

Leggae, D. G., \& Kim, S. (2021). Equitable access to COVID-19 vaccines: Cooperation around research and production capacity is critical. Journal for Peace and Nuclear Disarmament, 4(S1), 73-134.

Leslie, A. (2009). Sustainable communities: The role of global citizenship education. POLIS Journal, 2, $1-44$.

Levine, J. (2014). Teaching about the wider world: TC launches a unique program to help US teachers think globally. Teachers College Newsroom. http://www.tc.columbia.edu/articles/2014/september/ teaching-about-the-wider-world-tc-launches-a-unique-program/

Maas, W. (2014). European Union citizenship in retrospect and prospect. In E. F. Isin \& P. Nyers (Eds.), Routledge handbook of global citizenship studies (pp. 409-417). Routledge.

Maguth, B. M. (2012). Investigating student use of technology for engaged citizenship in a global age. Education Science, 2(2), 57-76.

Marzall, K. (2005). Environmental extension: Promoting ecological citizenship. Environments Journal, $33(3), 65-77$. 
McCausland, T. (2020). COVID-19's impact on globalization and innovation. Research-Technology Management, 63(6), 54-59.

McCormick, J. (1999). Understanding the European Union: A concise introduction. Palgrave Macmillan.

McKinley, J. (2012). Pop stars join growing effort to aid the poor. The New York Times. https://www.nytim es.com/2012/08/23/arts/music/hugh-evans-29-force-behind-global-festival-on-great-lawn.html

Mendoza, S. (2007). Preparing students for the global economy. The Hispanic Outlook in Higher Education, $17(14), 12-14$.

Milman, N. B. (2015). Examining global and glocal awareness, knowledge, and competency. Distance Learning, 11(4), 1-4.

Motani, Y. (2007). The emergence of global citizenship education in Japan. In E. D. Stevick \& B. Levinson (Eds.), Reimagining civic education: How diverse societies form democratic citizens (pp. 271-291). Rowman \& Littlefield.

Mullens, J. B., \& Cuper, P. (2012). Fostering global citizenship through faculty-led international programs. Information Age Publishing.

Myers, J. P. (2006). Rethinking the social studies curriculum in the context of globalization: Education for global citizenship in the US. Theory and Research in Social Education, 34(3), 370-394.

Myers, J. P. (Ed.) (2020). Research on teaching global issues: Pedagogy for global citizenship education. Information Age Publishing.

Natalegawa, M. (2018). The future of ASEAN. Australian Institute of International Affairs. http://www.inter nationalaffairs.org.au/australianoutlook/the-future-of-asean/

Newlands, D. (2002). Economic globalisation and global citizenship. In N. Dower \& J. Williams (Eds.), Global citizenship: A critical introduction (pp. 213-221). Routledge.

Noddings, N. (2005). Educating citizens for global awareness. Teachers College Press.

OECD (2020). Public procurement and infrastructure governance: Initial policy responses to the coronavirus (COVID-19) crisis. https://www.oecd.org/coronavirus/policy-responses/public-procurement-andinfrastructure-governance-initial-policy-responses-to-the-coronavirus-covid-19-crisis-c0ab0a96

Oxfam (1997). A curriculum for global citizenship. Oxfam.

Oxfam (2006). Education for global citizenship: A guide for schools. Oxfam.

Partnership for 21st Century Skills (2009). P21 framework definitions (ED519462). ERIC. https://files.eric. ed.gov/fulltext/ED519462.pdf

Penner, J., \& Sanderse, J. (2017). The role of economic citizenship education in advancing global citizenship. Policy \& Practice: A Development Education Review, 24, 138-158.

Peterson, A., \& Warwick, P. (2015). Global learning and education: Key concepts and effective practice. Routledge.

Petit dit Dariel, O. (2009). Nursing education: In pursuit of cosmopolitanism. Nurse Education Today, 29(5), 566-569.

Pettifor, A. (2017). Brexit and its consequences. Globalizations, 14(1), 127-132.

Pike, G. (2008). Reconstructing the legend: Educating for global citizenship. In A. A. Abdi \& L. Schultz (Eds.), Educating for human rights and global citizenship (pp. 223-237). State University of New York Press.

Polèse, M., \& Stren, R. (Eds.) (2000). The social sustainability of cities: Diversity and the management of change. University of Toronto Press.

Putman, S. M., \& Byker, E. J. (2020). Global citizenship 1-2-3: Learn, think, and act. Kappa Delta Pi Record, 56(1), 16-21.

Reimers, F. (2020). Educating students to improve the world. Springer.

Reysen, S., \& Katzarska-Miller, I. (2013). A model of global citizenship: Antecedents and outcomes. International Journal of Psychology, 48(5), 858-870.

Roeper, A. (2008). Global awareness and gifted children: Its joy and history. Roeper Review, 30(1), 8-10.

Rothkopf, D. (1997). In praise of cultural imperialism? Effects of globalization on culture. Foreign Policy, 107, 38-53.

Rowe, D. (2007). Education for a sustainable future. Science, 317(5836), 323-324.

Ruby, A. (2014). Preparing global citizens. International Educator, 23(5), 54-57.

Saperstein, D. (2008). The European counterterrorist as the next US cold warrior: Why the United States should select from the German and British models of procedure, evidence, and oversight for national security wiretapping. Fordham International Law Journal, 32(6), 1947-1989.

Saperstein, D. (2010). America's republic Valhalla vanished: The rise and fall of the Hall of Fame for Great Americans. Hindsight Graduate History Journal, 4, 65-89.

Schattle, H. (2008). The practices of global citizenship. Rowman \& Littlefield.

Shaw, T. M., Grant, J. A., \& Cornelissen, S. (Eds.) (2011). The Ashgate research companion to regionalisms. Ashgate. 
Shore, C. (2000). Building Europe: The cultural politics of European integration. Routledge.

Singh, S., \& Singh, S. K. (2020). Practicing empathy during COVID19 pandemic. Annals of Clinical Trials and Vaccines Research, 3(1), 3.

Sisk, D. A. (2010). Fostering global awareness and global learning for gifted students. Gifted Education International, 27(1), 10-18.

Slavich, G. M., Roos, L. G., \& Zaki, J. (2021). Social belonging, compassion, and kindness: Key ingredients for fostering resilience, recovery, and growth from the COVID-19 pandemic. Anxiety, Stress, \& Coping, 9, 1-8.

Stiglitz, J. E. (2002). Globalization and its discontents. W. W. Norton \& Company.

Swanson, A. (2020). As new NAFTA takes effect, much remains undone. The New York Times. https://www. nytimes.com/2020/07/01/business/economy/usmca-takes-effect.html

Telò, M. (Ed.) (2014). European Union and new regionalism: Competing regionalism and global governance in a post-hegemonic era. Ashgate.

Trooboff, S., Vande Berg, M., \& Rayman, J. (2008). Employer attitudes toward study abroad. Frontiers, 15, $17-33$.

Tuca, S. (2014). The relationship between globalization and the economic crisis. The USV Annals of Economics and Public Administration, 14(1[19]), 120-126.

UN (2020). United Nations comprehensive response to COVID-19: Saving lives, protecting societies, recovering better. https://www.un.org/sites/un2.un.org/files/un_comprehensive_response_to_covid-19_june_ 2020.pdf

UNESCO (2002). UNESCO universal declaration on cultural diversity. http://www.unesco.org/new/filea dmin/MULTIMEDIA/FIELD/Tashkent/pdf/124687e_underwater_cultural_heritage_2001_eng.pdf

UNESCO (2015). Global citizenship education: Topics and learning objectives. https://unesdoc.unesco.org/ ark:/48223/pf0000232993

UNESCO (2016). National Commissions for UNESCO: Annual report 2016. https://qnc.edu.gov.qa/_Layou ts/QNC.News/QncDownload.aspx?trg=/ReportDocs/AnnualReport2017NatCom_En_Fr.pdf

UNICEF (2013). Global citizenship: A high school educator's guide (Grades 9-12). https://www.gcedcleari nghouse.org/sites/default/files/resources/Global\%20citizenship_1.pdf

Van Elteren, M. (2011). Cultural globalization and transnational flows of things American. In P. Pachura (Ed.), The systemic dimension of globalization (pp. 149-172). InTech.

Wang, J., Peyvandi, A., \& Coffey, B. S. (2014). Does a study abroad class make a difference in student's global awareness? An empirical study. International Journal of Education Research, 9(1), 151-162.

Wang, Y. (2007). Globalization enhances cultural identity. Intercultural Communication Studies, 16(1), $83-86$.

Werner, W., \& Case, R. (1997). Themes in global education. In I. Wright \& A. Sears (Eds.), Trends and issues in Canadian social studies education (pp. 176-194). Pacific Education Press.

Whitehead, D. M. (2015). Global learning: Key to making excellence inclusive. Liberal Education, 101(3), $6-13$.

Zayani, M. (2011). Media, cultural diversity and globalization: Challenges and opportunities. Journal of Cultural Diversity, 18(2), 48-54.

Zhao, L. (2014). The influence of the culture on managers' capital-budget decisions. International Journal of Accounting and Taxation, 2(4), 49-55.

Zimmerman, K., \& Benjamin, D. (2021). We studied one million students. This is what we learned about masking. The New York Times. https://www.nytimes.com/2021/08/10/opinion/covid-schools-masks. html

Zolo, D. (1997). Cosmopolis: Prospects for world government. Polity.

Publisher's Note Springer Nature remains neutral with regard to jurisdictional claims in published maps and institutional affiliations.

Evan Saperstein is a postdoctoral fellow in the citizenship education and history teaching research lab at the University of Montreal. For nearly a decade, Evan has served as an adjunct professor and a high school social studies teacher in New Jersey. His research interests include global citizenship education, social studies education, experiential learning, curriculum development, and pedagogy. 